\title{
Muslim Cultures and Pre-Islamic Pasts: Changing Perceptions of "Heritage"
}

\author{
R. Michael Feener
}

\begin{abstract}
This chapter explores a diverse range of historic Muslim experiences with and appreciations of pre-Islamic cultural legacies. I offer an overview of Muslim interpretations of Qur'anic verses urging believers to reflect on the visible traces of pasts connected with traditions of pre-Islamic Arabia and biblical literature, followed by an examination of a series of historical vignettes relating medieval and early-modern encounters between Muslims and the material remains of past civilizations in Egypt, India, and Indonesia. These case studies clearly demonstrate that there is no single, normative "Islamic" approach to the cultural heritage of pre-Islamic civilizations. Rather, conversations about the meanings of the past for contemporary life and visions of the future are dynamic discourses incorporating an expansive body of ideas and experiences across diverse communities.
\end{abstract}

Keywords Pre-Islamic • Islamization . vernacularization · Egypt . Indonesia $\cdot$ India

"Have they not travelled through the land and seen how their predecessors met their end? They were mightier than them: they cultivated the

R.M. Feener $(\bowtie)$

Oxford Centre for Islamic Studies / Faculty of History, University of Oxford, Oxford, United Kingdom

(C) The Author(s) 2017

T. Rico (ed.), The Making of Islamic Heritage, Heritage Studies in the Muslim World, DOI 10.1007/978-981-10-4071-9_3 
earth more and built more upon it..." (al-Rum/30:9). ${ }^{1}$ The trope of "travelling through the land" (yasirn fi'l-ard) to see the ruins of past civilizations occurs more than a dozen times in the Qur'an. ${ }^{2}$ For over 1,400 years, as Islamic civilization spread out of Arabia and across expanding regions of Africa and Eurasia, Muslims have borne this in mind and interpreted it in diverse ways as they came into contact-and to termswith a wide range of physical remnants of multiple pre-Islamic pasts. In interpreting these diverse monuments and ruins, recourse was often made to the meanings the Quran elsewhere ascribes to ancient sites in Arabia and neighboring countries. For example, in the Qur'anic sura (chapter) of al-Fajr/89:6-13, we read:

Have you [Prophet] considered how your Lord dealt with [the people] of 'Ad of Iram [the city] of lofty pillars, whose like has never been made in any land, and the Thamud, who hewed into the rocks in the valley, and the mighty and powerful Pharaoh? All of them committed excesses in their lands, and spread corruption there: your Lord let a scourge of punishment loose on them.

Here the scope of past civilizations extends beyond Arabia to one of the most powerful symbols of antiquity in the broader region: Pharaonic Egypt. Indeed, within Muslim tradition Egypt's monumental heritage became a particularly powerful site for such reflections as that country became first a province of an expanding Muslim empire, and later a major center of Islamic learning and literature in its own right.

\section{Egypt in Muslim Imaginations of the Pre-Islamic Past}

For more than 1,000 years, Egypt has been a site for some of the most complex negotiations by Muslims with the ruins of their pre-Islamic pasts. There, diverse views and relations to this heritage have been constantly negotiated and renegotiated since the earliest period of Islamic history. For not only did Muslims encounter the remains of a lost past in the form of massive stone monuments, but the particular civilization associated with them is one that has been extensively discussed in the text of the Qur'an itself. Egypt's Pharaonic past receives considerably more attention in Islam's scripture than do the passing references to Arabian antiquities such as the pillars of 'Ad and the stonework of Thamud. 
Indeed, the longest sustained narrative in the Quranic text is the story of Yusuf (the biblical Joseph) in sura $12 .{ }^{3}$ When Muslims came to Egypt and encountered the imposing ancient monuments there those ruins became indexed to the Qur'anic story in local lore and literary traditions-as with the identification of the pyramids with Yusuf's granaries, and ruins at Saqqara and in the Fayyum with the palace of Zulaykha/"Potiphar's wife" and the prison into which Yusuf was cast, respectively (Haarmann 1996). Beyond the story of Yusuf, the Qur'an also tells, evocatively and repeatedly, of Moses' (Ar. Musa) confrontation with Pharaoh. In these verses, the figure of Fira un-and, by extension, the realm of Egypt that he ruled-represents the most extreme form of arrogant unbelief. On the one hand, the evil image of the builder of the pyramids could stir Muslim resentment and anger or even inspire works of vandalism and attempts at destroying pre-Islamic monuments. On the other hand, the Qu'anic injunctions to reflect on the ruins of ancient unbelievers could also be extended to the Pharaonic-built heritage of Egypt, thus fostering a sense of the desirability of preserving them for purposes of religious and moral pedagogy. Indeed, as Egypt's ancient ruins came to be considered among the greatest wonders (' $a j a$ ' $i b$ ) of the world, they could also be understood by many medieval Muslims as a testament to the greatness of God's creation, as well as the power of His judgment (Haarmann 1980).

Over the course of Egypt's Islamic history, Muslims have held a range of views all along this spectrum. As Ulrich Haarman (1980, 59, 1996, 625) has demonstrated, reactions to the built heritage of the Pharaohs have included both Saladin's futile attempt to destroy the pyramids and the arguments of medieval authors such as al-Idrisi and al-Manufi in favor of a more tolerant perspective on their preservation. The motivations of those medieval Muslims who were attracted to visit the pyramids and other ruins of ancient Egypt were diverse and often went well beyond religious reflection on the vain folly of human arrogance-with the journey to see these marvels also including personal searches for both wisdom and entertainment (Haarmann 1991a). Some Muslim travelers of the Middle Ages noted their appreciation of the technical mastery required to construct works like geometrically perfect obelisks (Haarmann 1991b). Others saw the pyramids in particular as giant storehouses for buried caches of "hermetic" knowledge (Fodor 1970) ${ }^{4}$ — with a wide range of mythic genealogies explaining the story of who it was that built the pyramids to protect this wisdom, when, and why. ${ }^{5}$ 
At the same time there were other, less esoteric, traditions associated with Pharaonic Egypt as well. Several medieval authors relate legends about and report magical powers associated with the sphinx, which accordingly was viewed by some as a source of power for cures, protection, and divination (Haarmann 1978). Despite all this, there appears to have been relatively little enthusiasm among the local 'ulama' for campaigns to destroy this monument to the age of the Pharaohs. In fact, the acceptance of pre-Islamic monuments as abiding remnants of the country's past was at times defended through recourse to the example of the Prophet's companions, who reportedly walked in the shadow of these monuments themselves and yet never apparently launched any campaign for their destruction. ${ }^{6}$

Diverse encounters with pre-Islamic pasts in early Muslim history are also evident in artifacts, architecture, and textual traditions from many other parts of what is today identified as the "Arab World." During the Abbasid period, we find Muslim rulers figuring prominently in narratives of encounter and engagement with ruins across the region. Stories circulated of the caliph al-Ma'mun's entrance into the pyramid at Cheops, retold with considerable elaboration in the 1,001 Nights (Cooperson 2004). Less well known, perhaps, is the visit of the caliph al-Mutawakkil to Hims. The tenth-century Kitab al-Ghuraba (The Book of Strangers: Medieval Arabic Graffiti on the Theme of Nostalgia 1999, 58-59) relates that there the Commander of the Faithful "camped in a place between great churches and ancient ruins, which are pleasant to behold, and which the visitor does not want to leave." 7 The renowned fourteenth-century historian Ibn Khaldun was also fascinated by the abandoned remains of ancient structures and cities that he saw stretching from North Africa to the Arabian Peninsula. Robert Irwin (2003) has argued that such ruins in fact served as an important framework for his thinking about the civilizations that came before Islam, and what had become of them, in his massive work of historical scholarship.

\section{Buried Treasure and More Accessible Artifacts}

Some of the earliest surviving written sources for Islamic history-including the Sira ("Narrative" of the Prophet's biography) of Ibn Ishaq-present narratives of buried treasure found at the pre-Islamic sanctuary at Mecca (Guillaume 1955, 45-47). According to tradition, 'Abd al-Muttalib recovered a number of remarkable ancient objects when excavating the well of Zamzam within the sacred precincts. This treasure included swords, armor, and two gazelles made of gold. In his study of this textual tradition, 
Brannon Wheeler $(2006,11)$ has highlighted the ways in which this story draws "extensively on a number of ancient and late antique motifs, such as the burial of the temple implements, the divine origins of weapons, and the king as guardian of the sanctuary."

Fascination with the treasures of the past remained a distinct theme in the work of some of the most prominent thinkers of medieval Islam. For example, the renowned ninth-century philosopher, Ya'qub al-Kindi, wrote two works on astrological methods for finding and recovering buried treasure-in what might be seen as a rather self-serving interest in accessing the riches of the past (Burnett et al. 1997). The fifteenth-century Mamluk historian al-Maqrizi embraced such methodologies in support of his project to recover the past greatness-wealth, wisdom, and scientific knowledge-of ancient Egypt, which he believed to be buried and simply awaiting discovery beneath its sands (Irwin 2003, 227). Beyond the written page, ideas about and religious associations with buried treasure were also reflected in the construction and veneration of "long graves" of the type that can be found in sites stretching from Arabia to Southeast Asia (Wheeler 2006, 118). ${ }^{8}$

Treasures of the past, however, were not only believed to be buried and inaccessible-as others were visible and on display to Muslims in a number of cultural contexts. Across the Muslim world, religious sites were not only places of worship but also sometimes locations at which artifacts and elements of earlier built heritage were preserved and presented to believers in complex visual contexts. For example, in the grave complexes of Wali Songo (the "Nine Saints" traditionally associated with the Islamization of Java) are found many objects that both contribute to the aesthetic ornamentation of the venerated tombs and preserve materials indexing their pre-Islamic pasts, as well as their complex histories as Muslim religious sites as they developed over subsequent centuries. At the shrine of Sunan Bonang at Tuban (East Java) were preserved two stone lingas and an ornamented yoni (stylized representations of male and female genitalia, respectively) pedestal from an earlier Hindu sanctuary on the site, ${ }^{9}$ as well as numerous later Islamicate artifacts, including porcelain plates decorated with Arabic script embedded into the walls and entrance gate to the cemetery. ${ }^{10}$ Perhaps the most striking object preserved at the site, however, is a large, ornately detailed wooden sculpture depicting a forested mountain landscape dotted with buildings associated with local traditions of asceticism and pre-Islamic religious practice. ${ }^{11}$

Mosques have also functioned as repositories of special objects-physical points of connection and visual evocations of the complex pasts of many Muslim communities. In some striking cases, these objects originated as 
spoils of past wars. ${ }^{12}$ Famous examples of this include the Quwwat al-Islam mosque in Delhi. However other, lesser known, cases can be found all across the world. One particularly striking example can be found in Malabar-a region of southern India that was at the forefront of confrontations between the Portuguese and local Muslim (and Hindu) communities in the sixteenth century (Dale 1980; Makhdoom I 2012; Makhdum 2012; Muhammad 2015). Along this stretch of the Kerala coast there stands an old wooden mosque containing a minbar, of which the back of the top step is comprised of an ornate panel said to be part of a "holy chair" taken in battle against the Portuguese. At its center is an image of the Virgin Mary, the face of which has - rather delicately - been flattened out. While thus literally "defaced" in conformity with dominant interpretations of the proscription of figural images in Islamic devotional settings, the object is, however, otherwise not disfigured (though it is discreetly covered by a curtain during prayer times). ${ }^{13}$ Other artifacts from the same mosque include pieces of cannon shot of various sizes in both stone and iron, a shield suspended by a chain from the ceiling, and an ornamental European sword. The last of these items also serves a ritual purpose - as it is used as the staff held by the khatib (preacher) during the sermons accompanying Friday congregational prayers.

Swords and other weapons are used in this way in a number of historical mosques in other parts of the Muslim world as well. On the opposite coast of southern India, antique swords can be found at several older mosques in Tamil Nadu. Examples held at mosques in Kayalpatnam include that of the Rettaikullampalli (Mika'il Mosque), which was recovered along with a porcelain dish during the dredging of a tank in the yard, and another at the Khutba Sirupalli (Jami ' al-Saghir) that is used as a ritual staff by the khatib (preacher) during Friday congregational prayers (Shokoohy 2011, 107). Across the Bay of Bengal in Indonesia, the old mosque of Kasunyatan in Banten (West Java) has an antique iron sword prop modeled after $d h u^{2} l$-fiqar (the double-bladed sword gifted to Imam Ali by the Prophet) that is likewise used during Friday services. Elsewhere in West Java one finds iron-tipped spears used in the same way, such as the preacher's staff at the old Kejaksan mosque in Cirebon. These objects of diverse material forms and geographic origins serve in multiple ways, ranging from liturgical functions to signifiers of communal memory, and become invested with meanings that both coincide with and go beyond dominant conceptions of "heritage" in contemporary global discourses.

A new perspective on the complex cultural and historical legacies of Muslim communities that captures some of the dynamism and complexities of such 
engagements with pre-Islamic pasts has been developed by Shahab Ahmed in his posthumous magnum opus. His hermeneutical and "explorative" approach provides means for a new appreciation of the ways in which "Muslims acting as Muslims" have engaged in processes of "meaning making in terms of Islam" (Ahmed 2016, 357). Ahmed's model opens new ways to understand the significance of historical Muslim engagements with their pre-Islamic pasts that both complicates and constructively expands popular understandings of "heritage." In his discussion of the philosophical legacies of ancient Greece, for example, he argues for a conception of dynamic and accumulative tradition in which-as he provocatively poses it- "That Aristotle and Plato were not Muslims is simply irrelevant to their meaningful designation as Islamic." (Ahmed 2016, 347) Across a range of other examples from diverse fields including medicine, poetry, and the visual arts, Ahmed develops a vision of Islam as an "idiom" that allows for a more nuanced appreciation of the ways in which elements of pre-Islamic cultures have been reconstituted through the experiences of Islamization. (Ahmed 2016, 323-325)

As Islamic civilization continued to expand across Africa and Asia over the medieval and early modern periods, so did the range of ways in which Muslims came to embrace elements of their pre-Islamic pasts. This included a number of cases of appropriation wherein sites came to be reimagined in relation to "Abrahamic" tradition, such as "Adam's Peak" in present-day Sri Lanka. This site, just off the maritime trade routes from the Red Sea to Asia, was visited by Ibn Battuta in the fourteenth century as well as other Muslims in motion across the Indian Ocean since the Medieval Period (Alam and Subrahmanyam 2007, 148-149; Ibn Battuta 1994, 848-850). Along those same eastern routes, however, Muslims encountered the material cultures of diverse civilizations that had evolved wholly outside the Abrahamic framework of Islamic revelation history that was dominant across much of the Near East and the Mediterranean world. These strange new worlds engendered a wide range of responses. In his encyclopedic notes on the diverse branches of learning and literature available to Muslim readers of his day, the tenth-century Baghdadi bookseller Ibn Nadim was able to relate a number of reports in Arabic on what were at that time un-Islamized lands of India, China, and Southeast Asiaincluding the large and wondrous "temples of idols" found at Qimar (Angkor, in present-day Cambodia) and al-Sanf (Champa, in present-day Vietnam; Dodge 1970, 830). At about the same time, the Arab geographer Abu'l-Faraj provided his readers with a nuanced approach to how 
such religious images were supposedly understood and engaged in diverse ways by various non-Muslim communities (Nainar 2011, 105).

Over the centuries that followed, some of these Asian societies on the expanding frontiers of Islam eventually became Muslim themselves. In such contexts, emerging Muslim communities renegotiated their own relationships to more proximate non-Muslim pasts, where-unlike the case in Egypt - the ancient monuments of these landscapes were not signs of distant mysteries indexed to Islamic scripture, but bereft of cultural continuity with contemporary Muslim communities. Rather, they were more often tangible markers of a past that was not completely forgotten over the more recent and gradual conversion of local populations to Islam. Even in contexts of religious conquest along these new frontiers, however, Muslims were not uniformly crusading to destroy the physical embodiments of pre-Islamic culture and religious practice. As Carl Ernst (2000) has demonstrated in his study of an early seventeenth-century Persian text describing the Hindu cave temples of Ellora, an author characterized as exhibiting a "basically conservative Muslim attitude" toward religious innovation was nonetheless not only able to appreciate the aesthetic and political importance of the site, but even went so far as to chastise Sultan 'Ali 'Adil Shah for the destruction of other Hindu temples in Vijayanagar.

Further along the routes of Islam's eastward expansion, the Indonesian island of Java was the site of a "Hindu-Buddhist" kingdom that fell to a confederation of Muslim maritime port polities on the north coast in the sixteenth century (Pigeaud 1976). Both before and since, aspects of local pre-Islamic heritage have played a major role in defining the culture of Javanese Muslims (Ricklefs 2003). This is perhaps most apparent today in aspects of nonmaterial or "intangible" cultural heritage such as music, dance, puppetry, and literature patronized as court arts by the sultans of Java to this day (Florida 1995; Headley 2004; Pigeaud 1938; Sears 1996; Sumarsam 1995). The perseverance of such traditions has sometimes been characterized in terms of "pagan survivals" by anthropologists, historians, and modern religious reformists (albeit in the service of rather different respective agendas)-who viewed them as somehow compromising the "orthodox" Islamic credentials of local Muslim communities in Java. However the appropriation, preservation, and reinterpretation of pre-Islamic traditions is by no means exceptional in the history of Islamic civilization. In fact, similar discourses can be traced in the histories of many Muslim societies across Asia, Africa, and the Middle East through the medieval and early-modern periods as well. 


\section{Narrative Traditions and Textualized Traces OF THE ANCIENTS}

During the early centuries of Islamic history, narrative textual traditions developed in Arabic that involved the selective appropriation and deployment of elements from Jewish, Christian, and ancient Near Eastern literatures in order to fill out and enhance the lacunae characteristic of tellings of stories involving characters and events related in the Quran that were shared with these earlier traditions. This body of collected narrative material has come to be referred to in Arabic as isra'iliyyat, and it was often used as an aid in interpreting the Qur'anic text for generations of Muslims after the death of Muhammad as a subfield of Qur'anic exegesis (tafsir). While some commentators have critiqued or attempted to deny the validity of these older traditions, they were accepted by many scholars and laymen for centuries as a valuable legacy to aid Muslims in their attempts to contextualize and interpret the text of Qur'anic revelation.

Such use of this earlier literary heritage has, however, come to be widely rejected by many Muslim scholars and exegetes of later historical periods. We are thus led to ask how we might understand its importance for earlier generations of Muslims who lived in contexts much more historically proximate to the Prophet himself, and to consider the reasons for this shift in dominant views on this aspect of pre-Islamic heritage. To some extent, this reflects broader trends in Islamic thought and Muslim popular culture, which have increasingly tended over the later centuries toward a more exclusively scripturalist approach to "religion," and an increasing suspicion of "tradition" (Calder 1993). These developments, in turn, may also reflect something of a modern sense of the perceived stature of "Islam" vis-à-vis other cultures in the modern world under threat. In the premodern period an expanding Islamic civilization often dealt with elements of the other cultures it encountered from a position of strength, allowing Muslims the privilege of not only "tolerating," but actively preserving, transmitting, interpreting, and even incorporating elements of those traditions within a more expansive frame. The sense of cultural confidence that enabled such engagements with pre-Islamic pasts has, however, been significantly compromised by experiences of European imperialism.

Medieval Muslim appropriations and appreciations of the heritage of earlier civilization are often discussed in terms of "science" (broadly conceived), as in the frequent references made by both academic historians 
and in popular apologetics about the ways in which works of philosophy, mathematics, geography, medicine, and other fields of learning from "foreign civilizations" that had been translated into Arabic during the Abbasid period were developed and transmitted. In this, some important dynamics of medieval Muslim culture could be likened to that of some European thinkers during the Renaissance. For example, in his Genealogia Deorum Gentilium (On the Genealogy of the Gods of the Gentiles), Boccaccio argued against what was at the time dominant Christian doctrine that rejected the literary works of antiquity, along with the "pagan" gods and goddesses they depicted. Rather, he stressed that such works remained valuable as sources through which readers could appreciate "certain natural truths...together with the deeds and moral civilization of the Ancients" (Osgood 1956, 12). Such an appreciation, he emphasized, was possible precisely because of the confidence of European Christian civilization in his day, or in his own words: " today...our strength is very great; the universally hateful doctrine of paganism has been cast into utter and perpetual darkness, and the Church in triumph holds the fortress of the enemy. Thus there is the very slightest danger in the study and investigation of paganism" (Osgood 1956, 124).

Perhaps the most well-known example of a similar openness toward the heritage of pre-Islamic literature and learning in Muslim history is that of medieval Persia, in which a new "Islamicate" form of that language was put in the service of both preserving and giving new expression to classic works, including the epic tales of the country's ancient kings. While this literary tradition has been widely discussed and highly regarded by many scholars of Persia's Muslim history, analogous traditions in other Islamicate vernaculars have not generally received such widespread attention and appreciation. Casting a wider comparative view across such material, however, can give us a more developed sense of the diverse ways in which Muslims have come to understand and live with their diverse pre-Islamic pasts.

In surviving premodern texts from the Indonesian archipelago, for example, we find vivid instances of older Indic literary sources being used in the explication of proper Islamic doctrine. In a Javanese literary text known as the Serat Cabolek, a debate over the purportedly "heretical" teachings of a shaykh named Haji Mutamakin concludes with the victory of his court opponents, who framed their condemnation of Mutamakin's professed rejection of the outward forms of the Sharia through arguments supported by their own eloquent recitation of Old Javanese 'Hindu' poetry 
(Ricklefs 2014; Soebardi 1975). Here, the wisdom of Java's pre-Islamic ancients was deployed to define the very norms of Islamic 'orthodoxy in a condmenation of apparent docrtinal error.'

Other Javanese texts, such as the early-nineteenth-century Serat Centhini, present images of Muslim travelers wandering across the island to visit religious schools, consult with rural ascetics and holy men, and visit the ruins of Hindu and Buddhist temples. ${ }^{14}$ At such sites, the protagonists often meet with local guides and/or gurus who not only point out interesting ornamental features of pre-Islamic religious monuments but also expound upon their sources of inspiration and spiritual meanings. High on Central Java's Dieng Plateau, for example, Ki Gunawan instructs his guests (and readers of the text) about the symbolism of characters from Javanese tellings of the Sanskrit epic Mababharata (Serat Centhini 2015, 431-460). In another section of the Serat Centhini ( $i$ 2015, II: 90), we find Mas Cabolang and his companions slowly making their way up and around the seven ascending levels of the great Buddhist temple mountain of Borobudur, wondering as they go at the statuary and reliefs as one of them exclaims, "If only there were someone who could explain the stories, how happy I would be!" ${ }^{15}$ The following day, the caretaker of the nearby Candi Mendut guides the travelers to this smaller temple, which the text describes as having a roof "in the shape of a mosque," and where they are overwhelmed by the sense of the divine calm they feel in the presence of the great seated Buddha image in the inner chamber, where they decide to spend the night (Serat CenthiniDituturkan Ulang oleh Agus Wabyudi 2015, II: 91). ${ }^{16}$ These same companions later went on to visit the ruins of Hindu temples at Candi Sewu and Prambanan, where they gazed upon the relief carvings of topless women, and took in the scent of perfumed oils that continued to be poured on its statues as offerings by peddlers and prostitutes visiting these pre-Islamic sanctuaries on market days in search of good fortune. The text's protagonists then comment ambivalently on the devotion displayed to such graven images (Serat Centhini 2015, 123-135). ${ }^{17}$

These and other monuments to Java's pre-Islamic past have served as sites of pilgrimage throughout the island's later history, and in fact many have become even more popular destinations for both ritual and recreational purposes over recent decades. Such continuity of royal and religious sites after conversion to Islam is however not, as some have claimed, a mark of "Javanese exceptionalism." ${ }^{18}$ Rather, analogous cultural dynamics form well-established patterns across the Muslim world. High-profile 
examples include "World Heritage" sites such as the Church of the Holy Wisdom, re-designated as a mosque (Aya Sofia) following the Ottoman conquest of Constantinople. But examples can be found all across the routes of Islam's expansion. These monuments, moreover, are not only about conquest and destruction-for they also open windows onto the myriad ways in which dynamic interactions with pre-Islamic cultures contributed to the development of the many rich local traditions of vernacular Muslim expression that have developed in diverse societies alongside processes of Islamization.

Academic debates and public polemics concerning the takeover of sacred spaces and the use of spolia from pre-Islamic temples for the building of mosques have been particularly sharp in India. With one of the largest Muslim populations in the world-despite their status as a national minority-India has been the site of complex Muslim histories of contact, exchange, settlement, and conversion. The presence of Muslims in India stretches back to the earliest periods of Islamic history, when Muslim traders began sailing across the Arabian Sea and settling in communities along the coasts (Prange 2009; Wink 1999, 67-86). The earliest surviving purpose-built Islamic religious buildings in South Asiadocumented by Mehrdad Shokoohy at Bhadresvar in Gujarat-were constructed in the twelfth century by local Indian craftsmen who employed traditional construction techniques and styles of ornamentation. In these new Muslim religious buildings, they incorporated monolithic columns of alternating geometric registers, reminiscent of linga shafts found in Hindu temples of the region (Gravely 2006), while also integrating new elements imported to South Asia from other Muslim societies, including semicircular arches and hypostyle floor plans (Shokoohy 1988, 40). Similar dynamics informed the construction of other Indian mosques over the centuries that followed, particularly in the southern coastal regions of Malabar and Tamil Nadu (Shokoohy 2011; Tusa Fels 2011). In both cases, vernacular styles of mosque architecture developed that drew heavily upon their respective regional pre-Islamic traditions-but did so through the work of local craftsmen who created new, purpose-built mosques, rather than re-purposing materials looted from temples to pre-Islamic deities.

In some other parts of South Asia, however, Islamization followed in the path of military conquest coming down from the north, as in the case of the Ghaznavid expansion of the tenth through twelfth centuries. The historiography of Sultan Mahmud's campaigns - and his destruction of 
the temple at Somnath in particular-inform powerful narratives of iconoclasm that continue to shape cultural and political debates on Islam and its relation to pre-Islamic pasts today. As Jamal Elias $(2012,136)$ has argued in his critical examination of these discourses, however, "There is ample evidence to suggest that Muslim social elites did not see statues of Hindu gods as threatening or taboo in ways that always necessitated their destruction." He then points to other important factors involved that served to support arguments for preserving pre-Islamic religious sites and artifacts, including appreciations of their value as mirabilia and "the potential economic benefit of leaving temples and their cultures of pilgrimage intact, and in many cases Muslim rulers preferred to keep the idols as a source of revenue" (Elias 2012, 132). More recently, Waleed Ziad (2016) has provided striking new evidence in support of this last point in particular through his studies of a cache of Arabic-inscribed copper coins from a Hindu temple in Gandhara.

All through the history of Islamic expansion in South Asia, moreover, Muslims interacted with local cultures to together produce a remarkable range of new artistic, architectural, and literary monuments, which incorporated contributions by Muslims and non-Muslims alike. Today the heritage of creative fusion that produced these Indian Muslim vernacular traditions faces sharp criticism from several different religious groups espousing agendas of both theological and aesthetic "purification." Over recent decades some vocal segments of the Hindu Right in India have developed a popular discourse of rejection of what they deem to be the "pollution" brought to Mother India by the "foreign" invasions of "Persian" and "Turkish" Muslims. At the same time, a growing number of Muslims have become increasingly uncomfortable with aspects of their own heritage that appear to draw from the pre-Islamic cultural traditions of their communities, resulting in the disappearance of vernacular traditions of architecture and ornament, and their replacement by forms imagined to project more "universal"-as opposed to "vernacular"standards of an Islamic aesthetic.

Across southern India today, for example, we witness the rapid eclipse of traditional styles of vernacular mosque architecture as an increasing number of such buildings that have been identified by both international scholars and local cultural NGO activists as major monuments to the region's Muslim vernacular built heritage are being torn down by some members of their own religious communities and replaced by new structures of concrete and re-bar. Most often these new mosques are being 
built in rather plain styles, although usually with the addition of a minaret and/or a dome to prominently mark its exterior form as "Islamic." Speaking with people in some of these communities, the reasons given for such destruction and radically different reconstructions are often "practical" ones-including the need for more prayer space and/or the material decay of earlier wooden or cut-stone structures. Transformations of the architectural profiles of communities in southern India, however, also reflect broader shifts in Islamic religious sensibilities influenced by currents of modernizing reform, which have gained ground across many parts of the Muslim world since the latter decades of the twentieth century. These modern intellectual and ideological developments have had significant effects on conceptions of identity in relation to the material culture and built heritage of a number of Muslim communities.

In the early decades of the twentieth century a number of prominent Egyptians had positively pointed toward the ruins of their country's preIslamic past in defining modern visions of nationalism (Wood 1998). However, reference to the monuments of the Pharaonic past (and the evocation of ancient styles in modern structures) as symbols of national pride have since become distinctly problematic for many of its modern citizens. Whereas some early Egyptian nationalists appealed to the monuments of the Pharaonic age as markers of a proud regional distinction, the assassin of Anwar Sadat in 1981 proclaimed to have "killed Pharaoh!" Such dramatic redeployments of the symbolism of the cultural heritage of pre-Islamic pasts track alongside the rise of political Islamist movements, Salafi scripturalism, and da'wa (proselytizing of Islam) projects of religious revival across much of the Muslim world since the 1970s.

Rejection of pre-Islamic heritage as symbols for contemporary Muslim communities are often expressed in the language of "purification" prominent in many major streams of modern religious reformism, from the Salafi scripturalism popularized by Rashid Rida, to Sayyid Qutb's clarion call for the rejection of jabiliyya (barbarism) in all its forms, and the post-petrol boom Saudi sponsorship of scripturalist reform projects around the world. The calls of such modern reform movements to distance contemporary Muslims from both what they see as "innovations" or "accretions" of the histories of their communities, as well as survivals from the "pagan" heritage of their pre-Islamic pasts, have themselves been evolving over the past century, following the Geist of a changing political climate. Since the second half of the twentieth century, Muslim discourses have taken shape around what are believed by some to be more exclusively "Islamic" 
conceptions of legitimate heritage-from modern Arabic conceptions of turath ("heritage") to Malaysian discourse on tamaddun Islami ("Islamic Civilization"). These discourses have tended to marginalize, and in many cases to actively denigrate, elements of heritage grounded in the preIslamic pasts of Muslim communities - while introducing new and increasingly influential models of Muslim antagonism toward pre-Islamic pasts that stand in sharp contrast to that presented in the discussion above of Shahab Ahmed's (2016) reading of earlier historical experiences of meaning making.

Over recent decades such shifts in meanings ascribed to pre-Islamic cultural legacies can be tracked across many parts of the broader Muslim world, and not only toward surviving stone statues and monuments. In Indonesia, for example, popular modes of cultural practice associated with local traditions came to be pejoratively labeled as abangan (Javanist," or only "nominally Muslim"), and those so labeled came under increasing pressure to "purify" their understanding of religion by rejecting association with perceived "survivals" of their pre-Islamic cultural heritage (Ricklefs 2012, 371-407). Recent violent Muslim reactions against the symbols of pre-Islamic pasts include the calls of Indonesian Islamists for the dismantling of Borobudur, ${ }^{19}$ the smashing of Buddha images at the Museum of the Maldives in 2012, ${ }^{20}$ the much-publicized demolition of the monumental Buddha images at Bamiyan by the Taliban in 2001, ${ }^{21}$ as well as the recent and ongoing destruction of both medieval Muslim and earlier pre-Islamic monuments in areas of the Middle East under the control of the Islamic State. This rising wave of destruction has fostered a growing sense of threat among those concerned with heritage over the fate of sites in the Muslim world. It is in this context that the International Criminal Court in The Hague has recently made its first ever conviction for the destruction of historical buildings as a war crime. ${ }^{22}$

At the same time, however, there is also a need to recognize evidence of a more positive appreciation of pre-Islamic pasts among contemporary Muslims in several countries. Even Saudi Arabia-a country's whose official interpretation of Islam places great emphasis on purification-has, for example, supported ground-breaking archaeological work at pre-Islamic sites including Qaryat al-Faw. This work has resulted in the discovery and publication of striking artifacts reflecting the reception and vernacularization of Hellenistic culture in the Arabian Peninsula during the early centuries of the Common Era, which has served to significantly reshape our picture of the religious and cultural contexts of Arabia before the rise of Islam. ${ }^{23}$ Arab 
engagements with the pre-Islamic culture of Mediterranean Hellenism clearly continued well after the rise of Islam, as evidenced by the late eighth-century mosaics of Umm al-Resas and the paintings of the Qusayr 'Amra in Jordan. Monuments such as these reflect in striking ways how some of the earliest generations of Muslims engaged actively and appreciatively with elements of the pre-Islamic past. ${ }^{24}$ There are thus both well-developed precedents for-and significant new work being done today by-Muslims exploring diverse aspects of relations to their pre-Islamic heritage. The range of ways in which this has happened and continues to occur across many areas of the Muslim world demonstrate that there is no single "Islamic" approach to the concept of heritage. Rather debates about the meaning of the past for life in the present and visions of the future are dynamic discourses incorporating an expansive body of ideas and experiences across diverse communities within the Muslim world.

\section{Notes}

1. Unless otherwise noted, all translations of Qur'anic passages in this paper are those of M.A.S. Abdel Haleem (2010).

2. Al 'Imran (3):137, al-An'am (6):11, Yusuf (12):109, al-Nabl (16):36, alHajj (22): 46, al-Naml (27):69, al-Rum (30):9 \& 42, al-Mala' ika (35):44, al-Mu'min (40):21 \& 82, and Muhammad (47):10. One of these verses, al-'Ankabut (29):20, however, focuses more on nature as God's creation rather than on the ruins of human civilizations.

3. In this chapter of the Quran, we also find one of the uses of the trope of "travelling through the land" in verse109: "...Have the [disbelievers] not travelled through the land and seen the end of those who went before them?..."

4. Fodor (1970) reconstructs and presents a series of complex genealogies and narratives that relate traditions that center on Hermes, Surid, and Shaddad b. 'Ad.

5. Michael Cook (1983) has demonstrated that this tradition associating the pyramids with Hermitic wisdom tradition is not, however, continuous with local Coptic heritage, but rather something that seems to have originated elsewhere in the medieval Muslim world — particularly in Iraq-and was later introduced into conversations on Egypt's wonders among Muslims across the Middle East.

6. Indeed, it was even said that one of them had scribbled graffiti on one of the pyramid blocks. Haarmann (1980) suggests that this might still survive to this day in a bit of illegible Kufic at Abu Sir. 
7. Tropes of the pleasures of visits to Christian monasteries can be traced back to the pre-Islamic period and continue through the poetry of the sixthcentury Imru' al-Qays to al-Isfahani in the tenth-becoming a staple of new genres that flourished under the patronage of Muslim rulers. See, Elizabeth Key Fowden, "The Lamp and the Wine Flask, Early Muslim Interest in Christian Monasticism."

8. Perhaps the most famous of these was that associated with Eve in Jeddah-at least until its destruction in 1928. Long graves (kubur panjang) can be found in many parts of Southeast Asia, often at sites associated with the early history of Islamization in the region, although in many cases they may be later embellishments to earlier monuments on site. Notable examples include the royal burial complex at Pasai (Aceh, Sumatra) and in the cemetery of Fatima bint Maimun in Gresik (East Java).

9. Two simple lingas are still embedded in situ on either side of the gateway into the middle yard of the cemetery. The yoni, which had long been situated inside a large ablution pool on site, has been moved to the nearby museum on the central square of Tuban.

10. Such Arabic-script plates are found at a number of historic Muslim mosques and shrines across the region. They are, for the most part however, not ancient artifacts but generally date from the nineteenth century. Many of the most commonly found plates of this type were produced in England during the nineteenth and early twentieth centuries for an export market that included Mecca-whence they were purchased by pilgrims as souvenirs (Mols 2013). In Southeast Asia, many examples of such plates were subsequently installed as ornaments at earlier sites, including the graves of some of Java's pioneering Islamic wali (Chambert-Loir 2011). Other examples can be found at the Kudikhao Mosque in Bangkok-a signature monument of Thai Muslim vernacular architecture.

11. This remarkable object is now housed near the cemetery in the Museum Kembang Putih. See Rony Firman Firdaus, Kalpataru: Media Merajut Harmoni antar Umat Beragama-Lomba Deskripsi Koleksi Unggulan se Jawa Timur Tahun (2012); Hélène Njoto, "À Propos d'une Pièce en Bois Sculptée de l'Art du Pasisir."

12. It should be noted, however, that in many cases observers had mislabeled as temple spolia elements that had actually been purpose-built for mosques, but executed in pre-Islamic vernacular styles. Finbarr Flood (2009, 47) remarks on this in connection with the monuments of Bhadreshvar in Gujarat. For more on the aesthetics and politics of the use of actual spolia in Islamic India, (Ibid., 121-226).

13. This striking image is generally covered with a cloth curtain, especially during prayer times. 
14. The complete Javanese text has been edited and published in the original Javanese by Yayasan Centhini in Yogyakarta. Dutch and Bahasa Indonesia summaries of its contents have been published by Theodore Pigeaud, "De Serat Tjabolang en de Serat Tjenthini: Inhoudsopgaven," and Ki Sumidi Adisasmita, Pustaka Centini: Ikbtisar Selurub Isinya. An Indonesian-language translation was undertaken and published in two stages, the first volumes appearing from the Balai Pustaka press (volumes 1-4), and the remainder published by Gadjah Mada University Press. It has also recently been published in an Indonesian-language adaptation: Serat CenthiniDituturkan Ulang oleh Agus Wahyudi. A heavily illustrated, but textually rather loose, English overview of the text can be found in Soewito Santoso, The Centhini Story: The Javanese Journey of Life.

15. Serat Centhini - Balai Pustaka edition II: 56.

16. Serat Centhini - Balai Pustaka edition II: 57.

17. Serat Centhini (Cakrawala edition) III: 131-132; Balai Pustaka edition III: 87-88.

18. The adaptation of older Hindu religious sites in Southeast Asia for use by latter-day communities converted to other religions is also seen, for example, in the contemporary practice of Theravada Buddhists at the caves and rock shelters of Phnom Kulen, Cambodia. See, Helen Ibbitson Jessup, "The Rock Shelter of Peung Kumnu and Visnu Images on Phnom Kulen."

19. Islamists had carried out a bombing at Borobudur in 1985 that caused some damage. Since then there have been some sporadic calls for further destruction, but threats have significantly increased since 2014, when the Islamic State targeted this ninth-century Buddhist monument in a Facebook post. Aaron Akinyemi, "Isis Threat to Ancient Buddhist Temple Puts Indonesia Police on Alert."

20. This was not the first act of modern Maldivian Muslim iconoclasm. A large Buddha statue discovered on a 1959 expedition to the island of Thoddu was first decapitated by a member of the local community before being brought back to the presidential palace at Malé, where vandals smashed it completely to bits within a week. See, Robinson, The Maldives: Islamic Republic, Tropical Autocracy, 131.

21. On this act of destruction in relation to both deeper historical dynamics of Muslim iconoclasm and contemporary political contexts, see Elias, "Un/ Making Idolatry: From Meccas to Bamiyan.”

22. On September 27, 2016, Ahmad al-Faqi al-Mahdi was convicted over the 2012 destruction of a mosque and nine mausoleums in Timbuktu (Male). See, Camila Domonoske, "For First Time, Destruction of Cultural Sites Leads to War Crime Conviction." 
23. For an overview of recent archaeological work on the pre-Islamic Arabian Peninsula, see: Roads of Arabia: Archaeology and History of the Kingdom of Sandi Arabia.

24. On this site, see Garth Fowden, Qusayr 'Amra: Art and the Ummayad Elite in Late Antique Syria.

\section{BiBLIOGRAPHY}

Abdel Haleem, M.A.S. 2010. The Qur'an: English Translation, with Parallel Arabic Text. Oxford: Oxford University Press.

Adisasmita, Ki Sumidi. 1975. Pustaka Centini: Ikbtisar Seluruh Isinya. Yogyakarta: U.P. Indonesia.

Ahmed, Shahab. 2016. What Is Islam? The Importance of Being Islamic. Princeton, NJ: Princeton University Press.

Akinyemi, Aaron. 2014. "Isis Threat to Ancient Buddhist Temple Puts Indonesia Police on Alert.” 23 August. http://www.ibtimes.co.uk/isis-threat-ancientbuddhist-temple-puts-indonesia-police-alert-1462352

Alam, Muzaffar, and Sanjay Subrahmanyam 2007. Indo-Persian Travels in the Age of Discoveries. Cambridge: Cambridge University Press.

Ali, Abdullah Yusuf. 1938. The Holy Qur-an: Text, Translation, and Commentary. 3rd ed. Kashmiri Bazar, Lahore: Shaik Muhammad Ashraf.

Burnett, Charles, Keiji Yamamoto, and Michio Yano 1997. "Al-Kindi on Finding Buried Treasure." Arabic Sciences and Philosophy no. 7: 57-90.

Calder, Norman. 1993. "Tafsir from Tabari to Ibn Kathir: Problems in the Description of a Genre, Illustrated with Reference to the Story of Abraham." In Approaches to the Qur'an, edited by Gerald R. Hawting and Abdel-Kader A. Shareef, 101-140. London: Routledge.

Chambert-Loir, Henri. 2011. "Melahap Teks: Piring-Piring Inggris Berhiasan Sajak Melayu." In Sultan, Pablawan dan Hakim, edited by Henri ChambertLoir. Jakarta, Indonesia: Kepustakaan Populer Gramedia.

Cook, Michael. 1983. "Pharaonic History in Medieval Egypt." Studia Islamica no. 57: 67-103.

Cooperson, Michael. 2004. "Al-Ma'mun, the Pyramids, and the Hieroglyphs." In Abbasid Studies II: Occasional Papers of the School of 'Abbasid Studies, Leuven, 20 June-1 July, 2004, edited by John Nawas, 165-190. Leuven, Belgium: Peeters.

Crone, Patricia and Shmuel Moreh. 1999. The Book of Strangers: Medieval Arabic Graffiti on the Theme of Nostalgia. Princeton, NJ: Markus Wiener.

Dale, Stephen Frederic. 1980. Islamic Society on the South Asian Frontier: The Mappilas of Malabar, 1498-1922. Oxford: Clarendon Press. 
Dodge, Bayard. 1970. The Fibrist of al-Nadim. Vol. 2. New York: Columbia University Press.

Domonoske, Camila. 2016. "For First Time, Destruction of Cultural Sites Leads to War Crime Conviction." Nationa Public Radio, 27 September. http:// www.npr.org/sections/thetwo-way/2016/09/27/495606932/for-firsttime-destruction-of-cultural-sites-leads-to-war-crime-conviction? $\mathrm{sc}=17 \& \mathrm{f}=$ \&utm_source=iosnewsapp\&utm_medium=Email\&utm_campaign=app.

Elias, Jamal J. 2007. “(Un)making Idolatry: From Mecca to Bamiyan.” Future Anterior: Journal of Historic Preservation, History, Theory, and Criticism no. 4 (2): 12-29.

Elias, Jamal J. 2012. Aisha's Cushion: Religious Art, Perception, and Practice in Islam. Cambridge, MA: Harvard University Press.

Ernst, Carl W. 2000. "Admiring the Works of the Ancients: The Ellora Temple as Viewed by Indo-Muslim Authors." In Beyond Turk and Hindu: Rethinking Religious Identities in Islamicate South Asia, edited by David Gilmartin and Bruce B. Lawrence, 98-120. Gainesville: University Press of Florida.

Firman Firdaus, Rony 2012. Kalpataru: Media Merajut Harmoni antar Umat Beragama-Lomba Deskripsi Koleksi Unggulan se Jawa Tumur Tahum 2012. Tuban, Indonesia: UPTD Museum Kembang Putih.

Flood, Finbarr B. 2009. Objects of Translation: Material Culture and Medieval "Hindu-Muslim" Encounter. Princeton, NJ: Princeton University Press.

Florida, Nancy. 1995. Writing the Past, Inscribing the Future: History as Prophecy in Colonial Java. Durham, NC: Duke University Press.

Fodor, Alexander. 1970. "The Origins of the Arabic Legends of the Pyramids." Acta Orientalia Academiae Hungaricae no. 23 (3): 335-363.

Fowden, Elizabeth Key. 2007. "The Lamp and the Wine Flask, Early Muslim Interest in Christian Monasticism." In Islamic Crosspollinations: Interactions in the Medieval Middle East, edited by Anna Akasoy, James E. Montgomery, and Peter E. Pormann, 1-28. Exeter, UK: Gibb Memorial Trust.

Fowden, Garth. 2004. Qusayr 'Amra: Art and the Umayyad Elite in Late Antique Syria. Berkeley: University of California Press.

Frank, Ute and Joachim Gierlichs, in collaboration with Sophia Vasilopoulou and Lucia Wagner. 2010. Roads of Arabia: Archaeology and History of the Kingdom of Saudi Arabia. Paris: Somogyi Art Publishers.

Ghabban, Ali Ibrahim, Béatrice André-Salvini, Françoise Demange, Carine Juvin, and Marianne Cotty 2010. Roads of Arabia: Archaeology and History of the Kingdom of Saudi Arabia. Paris: Somogyi Art Publishers.

Gravely, Frederick H. 2006. An Outline of Indian Temple Architecture. Chennai, India: Government Museum.

Guillaume, Alfred. 1955. The Life of Muhammad: A Translation of Ibn Ishaq's Sirat Rasul Allah. Oxford: Oxford University Press. 
Haarmann, Ulrich. 1978. "Die Sphinx: Synkretistische Volksreligiosität im Spätmittelalterlichen Islamischen Ägypten.” Saeculum: Jahrbuch für Universalgeschichte no. 29: 367-384.

Haarmann, Ulrich. 1980. "Regional Sentiment in Medieval Egypt." Bulletin of the School of Oriental and African Studies no. 43 (1): 55-66.

Haarmann, Ulrich. 1991a. "In Quest of the Spectacular: Noble and Learned Visitors to the Pyramids around 1200 A.D." In Islamic Studies Presented to Charles J. Adams, edited by Wael Hallaq and Donald P. Little, 57-67. Leiden, Netherlands: Brill.

Haarmann, Ulrich. 1991b. "Misalla." In The Encyclopedia of Islam, Second edition, 140-141. Leiden, Netherlands: Brill.

Haarmann, Ulrich. 1996. "Medieval Muslim Perceptions of Pharaonic Egypt." In Ancient Egyptian Literature: History and Forms, edited by Antonio Loprieno. Leiden, Netherlands: Brill.

Headley, Stephen. 2004. Durga's Mosque: Cosmology, Conversion, and Community in Central Javanese Islam. Singapore: ISEAS Press.

Ibn Battuta. 1994. The Travels of Ibn Battuta, A.D. 1325-1354 - Translated by H.A.R. Gibb with revisions and notes from the Arabic text edited by C. Defrémery and B.R. Sanguinetti. Vol. London: The Hakluyt Society.

Irwin, Robert. 2003. "Al-Maqrizi and Ibn Khuldun: Historians of the Unseen." Mamluk Studies Review no. 7 (2): 217-230.

Jessup, Helen Ibbitson. 2008. "The Rock Shelter of Peung Kumnu and Visnu Images on Phnom Kulen." In Interpreting Southeast Asia's Past: Monument, Image, Text, edited by Elisabeth A. Bacus, Ian C. Glover, and Peter D. Sharrock. Singapore: National University of Singapore Press.

Makhdoom I, Zainuddin 2012. Tabrid Ablil Imam ala Jibadi Abdati Sulban. Calicut, India: Other Books.

Makhdum, Zainuddin. 2012. Tuhfat al-Mujahidin: A Historical Epic of the Sixteenth Century. Calicut, India: Other Books.

Mols, Luitgard. 2013. Verlangen naar Mekka: De Hadj in Honderd Voorwerpen. Leiden, Netherlands: Rijksmuseum Volkenkunde.

Muhammad, Qadi. 2015. Fath al-Mubin: A Contemporary Account of the Portuguese Invasion of Malabar in Arabic Verse. Calicut, India: Other Books.

Nainar, Muhammad Husayn. 2011. Arab Geographers' Knowledge of Southern India. Calicut, India: Other Books.

Njoto, Hélène. 2014. "À Propos d'une Pièce en Bois Sculptée de l'Art du Pasisir (XVeS.-XVIIeS.): Le 'Kalpataru' du Musée de Tuban à Java-Est.” Archipel no. 88: 169-188.

Osgood, Charles G. 1956. Boccaccio on Poetry. New York: Library of Liberal Arts. Pigeaud, Theodore G. 1933. "De Serat Tjabolang en de Serat Tjenthini: Inhoudsopgaven." Verhandelingen van het Bataviaasch Genootschap no. 72 (2): $1-89$. 
Pigeaud, Theodore G. 1938. Javaanse Volksvertoningen: Bijdrage tot de Beschrijving van Land en Volk. Batavia (Jakarta, Indonesia): Volkslectuur.

Pigeaud, Theodore G. 1976. Islamic States in Java 1500-1700: A Summary of Eight Dutch Books and Articles by Dr. H.J. de Graaf. The Hague, Netherlands: Martinus Nijhoff.

Prange, Sebastian R. 2009. "Like Banners on the Sea: Muslim Trade Networks and Islamization in Malabar and Maritime Southeast Asia." In Islamic Connections: Muslim Societies in South and Southeast Asia, edited by R. Michael Feener and Terenjit Sevea, 25-47. Singapore: ISEAS Press.

Ricklefs, Merle Calvin. 2003. Mystic Synthesis in Java: A History of Islamicization from the Fourteenth to the Early Nineteenth Centuries. Norwalk, CT: East Bridge.

Ricklefs, Merle Calvin. 2012. Islamisation and Its Opponents in Java, c. 1930 to the Present. Singapore: NUS Press.

Ricklefs, Merle Calvin. 2014. "Cabolek." In Encyclopedia of Islam, THREE, edited by Kate Fleet, Gudrun Krämer, Denis Matringe, John Nawas, and Everett Rowson. Leiden, The Netherlands: Brill Online.

Robinson, John J. 2015. The Maldives: Islamic Republic, Tropical Autocracy. London: Hurst \& Company.

Santoso, Soewito. 2006. The Centhini Story: The Javanese Journey of Life. Singapore: Marshall Cavendish.

Sears, Laura. 1996. Shadows of Empire: Colonial Discourses and Javanese Tales. Durham, NC: Duke University Press.

Serat Centhini. 2015. 12 vols. Vol. 1. Yogyakarta, Indonesia: Cakrawala.

Shokoohy, Mehrdad. 2011. Muslim Architecture of Southern India: The Sultanate of Ma bar and the Traditions of the Maritime Settlers on the Malabar and Coromandel Coasts (Tamil Nadu, Kerala, and Goa). London: Routledge Curzon.

Shokoohy, Mehrdad with Contributions by Manijeh Bayani-Wolpert and Natalie H. Shokoony. 1988. Bhadreśvar: The Oldest Islamic Monuments in India. Leiden, Netherlands: Brill.

Soebardi, S. 1975. The Book of Cabolek: A Critical Edition with Introduction, Translation, and Notes. The Hague, Netherlands: Martinus Nijhoff.

Sumarsam. 1995. Gamelan: Cultural Interaction and Musical Development in Central Java. Chicago: University of Chicago Press.

Tusa Fels, Patricia 2011. Mosques of Cochin. Kochi, India: Mappin Publishing.

Wheeler, Brannon. 2006. Mecca and Eden: Ritual, Relics, and the Territory in Islam. Chicago: University of Chicago Press.

Wink, André. 1999. Al-Hind: The Making of the Indo-Islamic World. Vol. 1Early Medieval India and the Expansion of Islam, Seventh-Eleventh centuries. New Delhi, India: Oxford University Press. 
Wood, Michael. 1998. "The Use of the Pharaonic Past in Modern Egyptian Nationalism." Journal of the American Research Center in Egypt no. 35: 179-196.

Ziad, Waleed. 2016. “Islamic Coins' from a Hindu Temple: Reconsidering Ghaznavid Interactions with Hindu Sacred Sites through New Numismatic Evidence from Gandhara." Journal of the Economic and Social History of the Orient no. 59: 618-659.

R. Michael Feener is the Sultan of Oman Fellow at the Oxford Centre for Islamic Studies, and Islamic Centre Lecturer in the History Faculty at the University of Oxford, United Kingdom. He has published extensively in the fields of Islamic studies and Southeast Asian history, as well as on post-disaster reconstruction, religion, and development. His most recent monograph is Sharia and Social Engineering (Oxford University Press, 2014).

Open Access This book is licensed under the terms of the Creative Commons Attribution 4.0 International License (http://creativecommons.org/licenses/ by $/ 4.0 /)$, which permits use, sharing, adaptation, distribution and reproduction in any medium or format, as long as you give appropriate credit to the original author(s) and the source, provide a link to the Creative Commons license and indicate if changes were made.

The images or other third party material in this chapter are included in the chapter's Creative Commons license, unless indicated otherwise in a credit line to the material. If material is not included in the chapter's Creative Commons license and your intended use is not permitted by statutory regulation or exceeds the permitted use, you will need to obtain permission directly from the copyright holder.

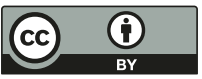

